\title{
A Brief Review of Lizard Inclusions in Amber
}

\author{
Miaoyan Wang and Lida Xing, ${ }^{\mathrm{a}, \mathrm{b}^{*}}$ \\ ${ }^{a}$ School of Earth Sciences and Resources, China University of Geosciences, Beijing 100083, China. \\ ${ }^{b}$ State Key Laboratory of Biogeology and Environmental Geology, China University of Geosciences, Beijing \\ 100083, China.
}

*Corresponding Author: Lida Xing.Email:xinglida@gmail.com

(C) The Author(s) 2020

\begin{abstract}
A total of 83 lizard specimens in amber have been reported around the world to date. Records of lizard inclusions extend from the Cretaceous to the Neogene: (1) Cretaceous lizard inclusions are dominated by Autarchoglossans from Lebanon and a diverse lizard fauna from Myanmar (Burma); (2) Paleogene lizard inclusions are relatively poorly preserved and are dominated by lacertids and gekkonids; (3) Neogene records are the most abundant, dominated by two extant genera, Anolis and Sphaerodactylus. Synthesizing important information from all reported specimens, we suggest that an investigation of lizard inclusions in amber is of great importance to the study of their evolution, community structure, and adaptive radiation as well as the origin and evolution of the adhesion mechanism in geckos and their level of ancient faunal diversity.
\end{abstract}

ARTICLE HISTORY

Received 21 February 2020

Revised 27 February 2020

Accepted 29 February 2020

\section{KEYWORDS}

Amber

Lizard inclusions

Cretaceous

Paleogene

Neogene

\section{Introduction}

Lizards are amongst the most diverse terrestrial vertebrates with more than 6,000 extant species (Pianka \& Vitt, 2003). Lizard species vary in individual size, external morphological characteristics, their osteological characters, and habitat. Thus, the results of research on lizards are important for fields such as ecology and evolutionary biology. For example, Anolis is an excellent model for community structure and adaptive radiations (Reilly et al., 2007; Sherratt et al., 2015). Our understanding of the phylogenetic and evolutionary history of lizards depends mostly on the discovery and study of lizard fossil records.

In contrast to a high number of extant lizards, however, fossils of great research value are very rare. Lizard fossils consist primarily of fossilized, disarticulated and scattered bones, with only few articulated (e.g., Daza et al., 2016; Bolet \& Evans, 2010; Conrad \& Norell, 2007; Gao \& Norell,
2000). Fortunately, in addition to fossils that have fossilized completely, a minority of specimens survive in the form of amber inclusions that preserve not only the skin with its ultrastructure but some internal organs and soft tissues (Grimaldi et al., 1994). Lizard inclusions in amber can therefore provide us with more intuitive, stereoscopic, and detailed morphological and anatomical information compared with traditional fossils providing an important basis for the study of behavior, phylogenesis, community structure, and species evolution.

As a result of strict environmental and taphonomic conditions for amber formation, mines that can support mining on a commercial scale are relatively rare. Thus, without substantial and sustained mining, the number of lizard inclusions would be severely limited. There are more than 160 amber mines around the world at present (e.g., Grimaldi, 1996; Martínez-Delclòs et al., 2004; Penney, 2010). Pieces of amber found 
to contain lizards mainly come from Europe (the Baltic), Asia (Myanmar and Lebanon), and Central America (Mexico and Dominica) covering a span of about 100 million years (Ma). Moreover, the oldest specimen can be dated back to $120 \mathrm{Ma}$ (Arnold et al., 2002). According to published papers, there are now more than 80 numbered specimens of lizard inclusions in amber (Fig. 1, Table 1), on top of undescribed and unpublished specimens found in private or public collections. This article organizes data from all published lizard inclusions in chronological order (from old to new) for the purpose of summarizing their significance to lizard evolution and phylogenetics as well as highlighting their adaptations to the ecological environment. These data will be helpful as we analyze amber lizards more effectively in the future and gain a better understanding of the evolution of diverse lizard groups.

\section{Cretaceous lizard inclusions}

These lizard inclusion specimens were described in Cretaceous amber from Lebanon and Myanmar and comprise a total of 15 pieces including the species Baabdasaurus xenuru (Arnold et al., 2002), Cretaceogekko burmae (Arnold \& Poinar, 2008), Barlochersaurus winhtini (Daza et al., 2018) and some unnamed specimens from Myanmar.

\section{Lebanese specimens}

Palynological analysis indicates that amber bearing deposits in Lebanon are located from the top Neocomian to the base of the Aptian of the Lower Cretaceous (Dejax et al., 1996; 1997). So far, only one specimen of amber lizard has been found in Lebanon (MNHN Entomology Azar 497), the snout-vent length (SVL) of which calculated to be $25-30 \mathrm{~mm}$, that makes the oldest reptile inclusion in the world. This specimen was collected by Dany Azar in the Hammana-Mdeyrij region of Baabda in central Lebanon and was later named as B. xenurus by Arnold et al. (2002). It has some external features common with Autarchoglossa including the main Scincomorpha clades and Autarchoglossa members such as enlarged tail scales and tubercular scales on feet soles and beneath the toes, which are very rare or even missing in iguanians and gekkotans. Arnold et al. (2002) 40 suggested that Baabdasaurus might be a sister group or member of Scincomorpha, or Anguidae. However, due to poor preservation and fragmentation of the specimen, its relationship at the family level is unknown and its taxonomic status remains uncertain.

In addition, considering the shape and size of the digits, the lateral expansion of the toes, strong keeling on the dorsal tail scales, and the behavior of existent lizards similar to Baabdasaurus, the specimen suggests that Baabdasaurus was able to climb on leafy herbaceous plants or inhabited lush vegetation to some extent (Arnold, 1973; 1998).

Overall, B. xenuru represents the oldest lizard fossil in amber today. The specimen provides the first direct evidence of external characteristics of early members of the Autarchoglossa clades, indicating that a series of these features common for autarchoglossans appeared as early as about $120 \mathrm{Ma}$ in the Early Cretaceous (Arnold et al., 2002).

\section{Burmese specimens}

Burmese lizard inclusions mainly come from the amber mines of Kachin located in north Myanmar. $\mathrm{U}-\mathrm{Pb}$ dating results show that the absolute age of amber in this area is $98.79 \pm 0.62 \mathrm{Ma}$ (Shi et al., 2012). Lizard inclusions are abundant in Myanmar. The Dexu Institute of Palaeontology (DIP, China) has collected more than 200 specimens, and there are also vast undescribed private collections scattered around the world.

Arnold \& Poinar (2008) discovered a lizard inclusion (Poinar Collection \#B-V-4, SVL $\leq 15$ $\mathrm{mm})$ in 2001 from the Noije Bum 2001 Summit Site $\left(26^{\circ} 20^{\prime} \mathrm{N}, 96^{\circ} 36^{\prime} \mathrm{E}\right)$ in the Hukawng Valley amber mine of Kachin state, and named it $C$. burmae. B-V-4 only preserved the lizard's left leg and foot, part of an isolated right foot and part of the tail. The specimen has the unique finger ratio of typical climbing gekkotans. For example, digits I-IV are quite similar in length, toe III is the longest, the adhesive toe pads are broad, and there are many transverse lamellae under the toes bearing adhesive setae (Arnold \& Poinar, 2008). 
Table 1. A summary of lizard inclusions in amber (Loc. = location; SVL = snout-vent length).

\begin{tabular}{|c|c|c|c|c|c|c|}
\hline ٌْ & $\stackrel{80}{4}$ & Serial number & Species & Maturity & $\begin{array}{l}\text { SVL } \\
(\mathbf{m m})\end{array}$ & Taxonomic status \\
\hline \multirow{2}{*}{ 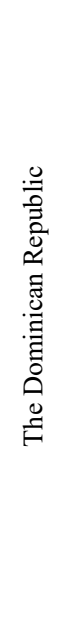 } & \multirow{2}{*}{ 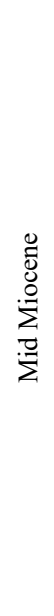 } & $\begin{array}{l}\text { NMBA Entomology P } \\
52 \\
\text { AMNH DR-SH-1 } \\
\text { SMU } 74976 \\
35 \text { scattered specimens } \\
\text { SMNS DHQ-4924-H }\end{array}$ & $\begin{array}{l}\text { Anolis dominicanus } \\
\text { Anolis sp. } \\
\text { Anolis sp. } \\
\text { Anolis spp. } \\
\text { Anolis sp. }\end{array}$ & $\begin{array}{l}\text { juvenile or } \\
\text { small-sized } \\
- \\
- \\
- \\
-\end{array}$ & $\begin{array}{l}26.5 \\
29 \\
- \\
- \\
-\end{array}$ & $\begin{array}{l}\text { Sauria: } \\
\text { Iguanidae: } \\
\text { Anolis }\end{array}$ \\
\hline & & $\begin{array}{l}\text { ZFMK } 66238 \\
\text { SMNS Do-3584-M } \\
\text { AMNH collection } \\
\text { MCZ R-186380 }\end{array}$ & $\begin{array}{l}\text { Sphaerodactylus } \\
\text { dommeli } \\
\text { Sphaerodactylus sp. } \\
\text { S. ciguapa }\end{array}$ & $\begin{array}{l}\text { adult } \\
\text { adult } \\
\text { juvenile } \\
-\end{array}$ & $\begin{array}{l}32.1 \\
16.5 \\
14 \\
33\end{array}$ & $\begin{array}{l}\text { Gekkota: } \\
\text { Sphaerodactylidae: } \\
\text { Sphaerodactylus }\end{array}$ \\
\hline$\frac{8}{\substack{x\\
}}$ & 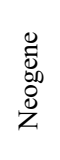 & $\begin{array}{l}\text { UCMP } 68496 \\
\text { UCMP } 68497 \\
3 \text { private collections }\end{array}$ & $\begin{array}{l}\text { Anolis elsctrum } \\
\text { Anolis spp. }\end{array}$ & $\begin{array}{l}\text { juvenile } \\
-\end{array}$ & $\begin{array}{l}26-31 \\
-\end{array}$ & $\begin{array}{l}\text { Sauria: } \\
\text { Iguanidae: } \\
\text { Anolis }\end{array}$ \\
\hline $\begin{array}{l}\vec{\Xi} \\
\text { 융 }\end{array}$ & \multirow{4}{*}{ 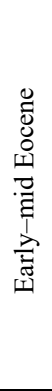 } & G.G.1 & $\begin{array}{l}\text { Succinilacerta } \\
\text { succinea }\end{array}$ & juvenile & 27 & Lacertoidea: \\
\hline \multirow[b]{3}{*}{ 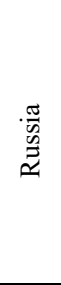 } & & MGPU 12664 & Su. succinea & - & - & Succinilacerta \\
\hline & & 10 private collections & Succinilacerta spp. & - & - & \\
\hline & & GAM 1400 & $\begin{array}{l}\text { Yantarogekko } \\
\text { balticus }\end{array}$ & $\begin{array}{l}\text { probably } \\
\text { adult }\end{array}$ & $20-22$ & $\begin{array}{l}\text { Gekkota: } \\
\text { Gekkonidae: } \\
\text { Yantarogekko }\end{array}$ \\
\hline \multirow{3}{*}{ 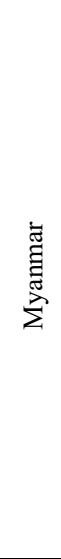 } & \multirow{3}{*}{ 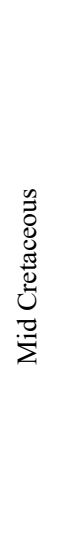 } & $B-V-4$ & $\begin{array}{l}\text { Cretaceogekko } \\
\text { burmae }\end{array}$ & juvenile & $\leq 15$ & Gekkota \\
\hline & & 12 scattered specimens & unknown & - & - & $\begin{array}{l}\text { the stem Squamata, } \\
\text { the stem Gekkota, } \\
\text { the crown Agaminae, } \\
\text { the crown Lacertoidea, } \\
\text { the stem Anguimorpha } \\
\text { (Barlochersaurus winhtini) }\end{array}$ \\
\hline & & F28461BUICJW & unknown & $\begin{array}{l}\text { probably } \\
\text { adult }\end{array}$ & - & Squamata: Agamidae \\
\hline 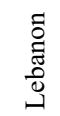 & 䔍 & $\begin{array}{l}\text { MNHN Entomology } \\
\text { Azar } 497\end{array}$ & $\begin{array}{l}\text { Baabdasaurus } \\
\text { xenurus }\end{array}$ & $\begin{array}{l}\text { probably } \\
\text { juvenile }\end{array}$ & $25-30$ & $\begin{array}{l}\text { An early member of } \\
\text { Autarchoglossa }\end{array}$ \\
\hline
\end{tabular}


Later, Daza et al. (2014) described another characteristic of climbing geckos with toe pads that is embodied in the B-V-4 specimen, namely the asymmetric claws (Daza et al., 2014; Russell \& Bauer, 1989). Though Cretaceogekko is similar to the extant Hoplodactylus and Phyllopezus species, it still differs from other extant geckos in toe proportions and toe pad structure (Bauer, 2019) hence it cannot be attributed to any extant genus. Arnold \& Poinar (2008) attributed Cretaceogekko to Gekkonidae. However, Daza et al. (2014) preferred to classify it as a member of Gekkota due to the fact that its relationship with Phyllodactylidae could not be completely excluded. Therefore, the taxonomic status of Cretaceogekko remains to be revised. The finding of one of the oldest fossilized geckos, C. burmae shows that geckos appeared on the Asian continent as early as the mid-Cretaceous period about $100 \mathrm{Ma}$, whereas typical toe proportions of climbing geckos, as well as complex toe pads with lamellae and adhesive setae similar to those of extant geckos developed through several evolutionary steps (Gamble et al., 2008).

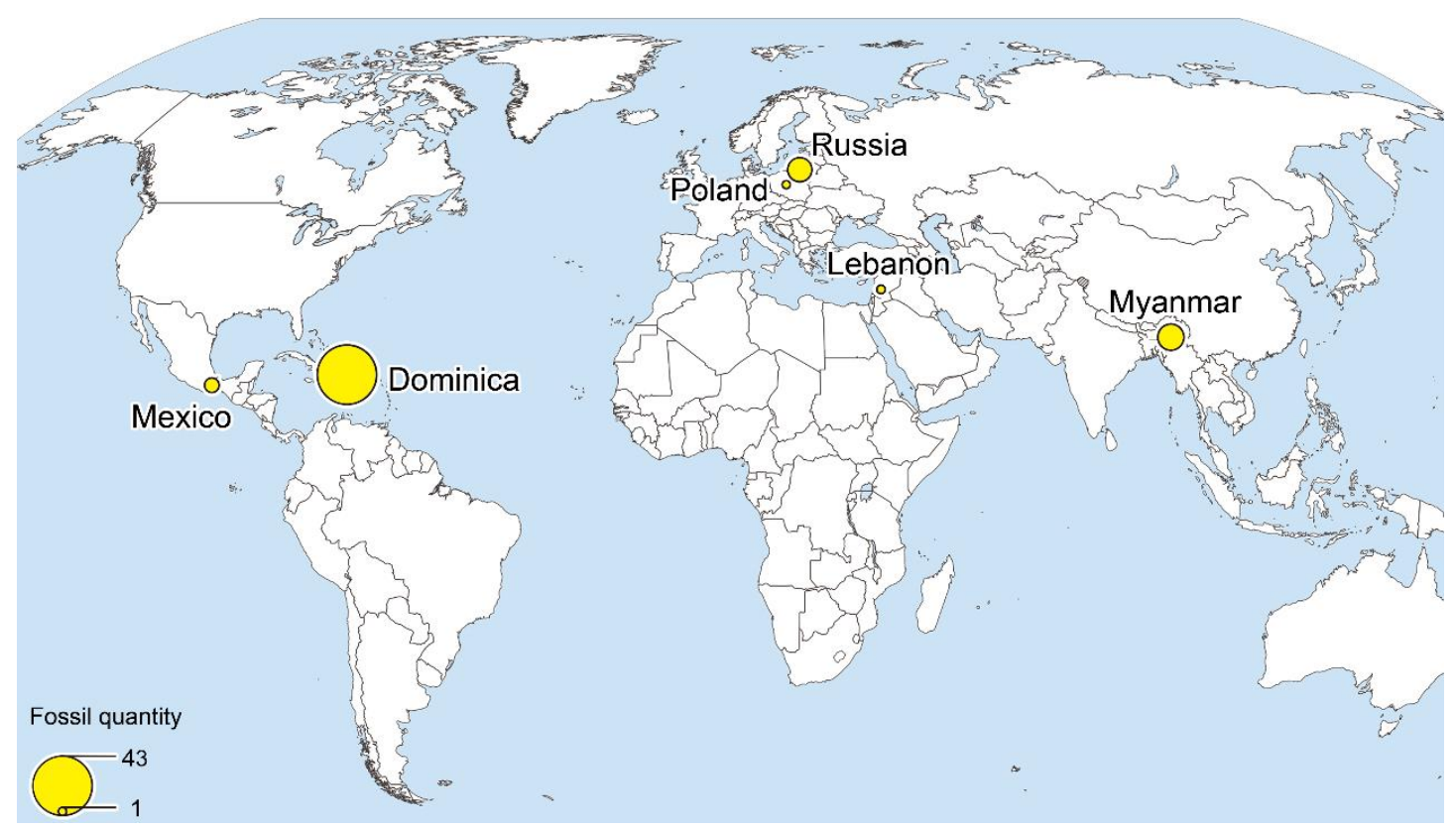

Fig. 1. The distribution and abundance of lizard inclusions found in Europe (Poland and Russia), Asia (Myanmar and Lebanon), and Central America (Mexico and Dominica).

Daza et al. (2016) reported on the most diverse ancient lizard fauna in amber, namely 12 specimens in total from Kachin, Myanmar. From these specimens MCZ R-190835 and MCZ R190836 are stored in the Museum of Comparative Zoology (MCZ), while the others are preserved in the American Museum of Natural History (AMNH). In general, the state of preservation of these lizard specimens is patchy and variable with JZC Bu267 and JZC Bu1802 being the only relatively complete and clear ones, while not all specimens have been named. These were attributed to 5 different clades after taxonomic analysis using high resolution x-ray computed tomography (HRXCT), scanning electron microscopy (SEM) and light microscopy. Consequently, JZC Bu267, AND-B-870, JZC Bu269 and JZC Bu1848 were assigned to the stem Squamata (the taxonomic status of which is uncertain); JZC Bu1847, JZC Bu1802 and MCZ R-190835 to Gekkota; JZC Bu266 and MCZ R190836 to the crown Agaminae; the others to the crown Lacertoidea. In addition to the fact that $C$. burmae was attributed to Gekkonidae sensu lato, the presence of the gecko fossils above clearly confirms the existence of geckos in the midCretaceous, and indicates that adhesive toepads appeared and developed into diversified structures during this period (Daza et al., 2016). In addition, the specimen JZC Bu154 mentioned therein was mistaken for a lizard and was assigned to the stem Chamaeleonidae. However, Matsumoto \& Evans (2018) later reclassified it as an Albanerpetontid, an extinct amphibian, with no detailed explanation. 
High resolution $3 \mathrm{x}$-ray computed tomography and linear discriminant analysis (LDA) based on skeletal variables were applied to analyze the subdigital structure of MCZ R-190835 and resulted in a subsequent detailed redescription of the anatomy of the specimen (Fontanarrosa et al., 2018). Linear discriminant analysis indicated an attribution of MCZ R-190835 to the interimistic zone shared by Gekkota and Scincomorpha. However, morphology-based evidence being more definitive, the shape of skeletal elements suggested that it was more related to Gekkota. Consequently, it was attributed to Gekkota with an unknown family affiliate. Furthermore, it was also concluded that the paraphalange, an accessory structure of toe pads, is not necessary for the adhesion mechanism based on qualitative and quantitative similarities between this specimen and both scansorial and non-scansorial squamata, and the fact that pad bearing and padless geckos have paraphalanges in common (Fontanarrosa et al., 2018).

Poinar et al. (2017) described trematode cysts in a fossilized lizard (F28461 BUICJW) included in new Burmese amber from the Noije Bum 2001 Summit Site mine. The metacercariae (encysted late stage larvae of a trematode) were located in cysts at the base of the femora. The lizard specimen is characterized by a long tail, vestigial claws, longer fourth digits on the manus and pes and a unique shape of the lateral scales. All of these features fit the characteristics of Agamidae (Witten 1989; Hutchinson et al., 2012; Daza et al., 2016; Poinar et al., 2017). Due to the head and neck missing the body length was estimated only to measure $85-92 \mathrm{~mm}$ within a range of adult agamids (Manthey \& Schuster, 1996). However, as the specimen in question was incomplete it was not described in detail nor analyzed phylogenetically. In addition, it revealed that lizards were among intermediate hosts (the larva's host) of trematodes about 100 million years ago (Poinar et al., 2017).

Daza et al. (2018) named a specimen in a private collection (Federico Barlocher collection 8, SVL $\approx 19.1 \mathrm{~mm}$ ) as Barlochersaurus winhtini, which was from the same mine in Kachin and had nine features to identify as Squamata as well as six to identify as Anguimorpha. The diagnostic features included (1) over 26 presacral vertebrae (Estes et al., 1988); (2) inwardly curved tooth crown
(Rieppel, 1994); (3) clearly constricted outer margin of the frontal; (4) backwards elongated external nostril; (5) the absence of nodules on the internal surface of the retroarticular process (Conrad, 2008); (6) about 20 maxillary tooth loci (Rieppel, 1980a). Based on the above characteristics, Daza et al. (2018) finally assigned the specimen to the stem Anguimorpha. Although the specimen is nearly intact, $\mathrm{x}$-ray images show a uniform density of soft tissue and bones making it difficult to identify the internal structure by CT scan. Since few detailed features could be specified, the phylogenetic status of this specimen and thus its affiliation remains unclear.

In summary, the lizard fauna found in Burmese amber comprises members of the stem Squamata, stem Gekkota, crown Agaminae, crown Lacertoidea and stem Anguimorpha revealing the diversity of Squamata in this region in the Cretaceous period (Daza et al., 2016, 2018). Moreover, the highly specialized adaptive paraphalanges of C. burmae and MCZ R-190835 indicate that despite the presence of climbing lizards in the Jurassic period (Simões et al., 2016), climbing ability assisted by adhesive paraphalanges only appeared in geckos in the mid-Cretaceous period (Fontanarrosa et al., 2018).

\section{Paleogene lizard inclusions}

Records of lizard inclusions in amber from the Paleogene period come mainly from Russian and Polish areas of the Baltic where amber was formed during the early to middle Eocene (54-42 Ma) (Keyser \& Weitschat, 2005). These inclusions comprise 13 specimens in total including Succinilacerta succinea (Böhme \& Weitschat, 1998; Borsuk-Bialynicka et al., 1999), Yantarogekko balticus (Bauer et al., 2005) and several fragmentized Succinilacerta spp. (Böhme \& Weitschat, 1998; 2002).

The results of glauconite dating within amber bearing sediment called "blue earth" in the Samland Peninsula of northwest Russia indicates that the amber was formed during the early Eocene ( $\sim 54 \mathrm{Ma})$ in this region (Ritzkowski, 1997; Wichard \& Weitschat, 2002).

The first amber lizard specimen in the Baltic (MGPU 12664) was found in Sambia (Samland), 
the city of Kaliningrad in Russia. Originally it was considered to be a member of Cnemidophorus (Klebs, 1889), but later was assigned to the extant Nucras genus, more specifically to Nucras succinea (Boulenger, 1917, 1920; Klebs, 1910). The specimen was later redescribed in detail and its name changed to $S$. succinea (Böhme \& Weitschat, 1998). At the same time, three other fragmented lizard specimens were also mentioned by these authors (private collections, no serial number) from the Yantarnyj region of the Sambia Peninsula. Among these, MGPU 12664 is relatively complete with a head, abdomen, part of the dorsum, a right forelimb and a pair of hind limbs, all of which are well-preserved, as well as the relatively clear scales making it the holotype of $S$. succinea. There is little information about other specimens, of which only two have several body parts preserved, such as hind limbs or a tail. These were classified as $S$. succinea together with seven other lizard inclusions found in the Baltic region (Böhme \& Weitschat, 1998, 2002). A further specimen (G.G.1, SVL $\approx 27 \mathrm{~mm}$ ) found in Holocene beach sediments of the Gdańsk-Stogi area of Poland was also classified as S. succinea (Borsuk-Bialynicka et al., 1999). This has the skin preserved, but not the endoskeleton. Important clues of this taxonomic relationship are provided by morphological features of its pileus. Five features of this specimen were identified to make it a Lacertid, hence it was argued that Succinilacerta should belong to that crown or a clade including Lacertids.

Succinilacerta was considered an extinct monotypic genus by Borsuk-Bialynicka et al. (1999), even though at least three different Succinilacerta species have been described from Baltic amber (Böhme \& Weitschat, 2002; BorsukBialynicka et al., 1999; Daza \& Bauer, 2012; Katinaa, 1983; Kosmowska-Ceranowicz et al., 1997a, 1997b; Krumbiegel, 1998).

Bauer et al. (2005) described a fossilized lizard (GAM 1400, SVL = 20-22 $\mathrm{mm}$ ) in amber from the Lower Eocene strata of the Sambia Peninsula, and subsequently named it Yantarogekko balticus. This specimen was designated as the holotype of the new species. It has well developed, unsplit subdigital scansors and is lacking movable eyelids, both of which indicate links to the Gekkonidae family. In addition, it has a highly 44 asymmetrical digit ratio, namely much smaller digits I-II than digits III-V. Further differences from other geckos include a unique scansorial structure and a reduced but robustly clawed digit I (Russell \& Bauer, 1990). Nevertheless, the specimen in question exhibits a sophisticated adhesive system similar to that of modern climbing geckos (Autumn \& Peattie, 2002). It was suggested that Yantarogekko might be either a divergent clade that existed before the common ancestor of all extant geckos or is an extinct derived member of the modern Gekkonidae, hence the obscure affiliation (Bauer et al., 2005). Moreover, Daza et al. (2014) pointed out that the external characteristics of this holotype did not provide sufficient ground to identify clues of further relationships, thus it could only be identified as a non-eublepharid gecko based on geographical distribution (Oliver \& Sanders, 2009). Detailed internal anatomical features are needed for further attribution of its taxonomic status. On the whole, GAM 1400 is still considered the oldest gecko found in Baltic amber.

\section{Neogene lizard inclusions}

These originate mainly from Mexico and the Dominican Republic of Central America. Dominican amber was formed approximately in the middle Miocene (20-15 Ma); indeed, while the age of Mexican amber remains subject to debate, this can range from the Late Oligocene to the Early Miocene (22.5-26 Ma) (Langenheim, 1966; Poinar, 1992; Poinar \& Brown, 2002) or the Middle Miocene, whereas Dominican amber was formed around the same period (Grimaldi, 1995; Itturralde-Vinent \& MacPhee, 1966; Morayma Solórzano Kraemer, 2007). Described Neogene amber lizards consist of 48 specimens dominated by the two extant genera Anolis and Sphaerodactylus.

\section{Mexican specimens}

Almost all amber lizards found in Mexico have been assigned to the extant Anolis, the largest and most diverse genus of extant reptiles. These were divided into two different types, the Alpha Anolis type and Beta Anolis type by Etheridge (Etheridge, 1959, 1965) based on osteological features. In contrast to the Beta type, the transverse process 
on the caudal vertebrae is minute or lacking in the Alpha type. Furthermore, two key features in the morphology of the interclavicle and its connection with the extension of the lateral process provides a base for a further division into two main clades: a T clade and an Arrow clade (Etheridge, 1959, 1965; Poe, 2004; Williams, 1976, 1989).

The earliest records (UCMP 68496, UCMP 68497) of Anolis fossils come from Simojovel de Allende in Chiapas, Mexico. These two specimens were identified as a new species, Anolis electrum by Lazell (1965). Most of the Mexican amber has been found in the area (Penney, 2010). Based on a trace of vitelline membrane on the abdomen of the holotype (UCMP 68496), it is thought to be a hatchling. Considering snout-vent length ( $26-$ $31 \mathrm{~mm}$ ), this may be an unspecialized or nonminiaturized Anolis. Considering scale morphology, the species was thought to be closest to the extant species A. limifrons (Lazell, 1965). To estimate the time period when Anolis appeared, the phylogenetic status of $A$. electrum and the estimated age of Mexican amber were compared (Nicholson et al., 2012). Poe (2004) listed 91 morphological features of Anolis, where ten were found to correspond with A. electrum. Based on new data obtained by HRXCT, the 3D model of A. electrum was reconstructed, the features of scales and dewlaps redescribed and a topological analysis conducted to confirm that the so-called holotype and paratype (UCMP 68497) of $A$. electrum actually belonged to the same individual (Castañeda et al., 2014). However, due to the fragmentary nature of specimens, morphological characteristics useful for phylogenetic analysis are very limited. Among the 14 most parsimonious trees only one shows a close relationship between $A$. electrum and an extant species, A. chloris (Castañeda et al., 2014). Although the relationship between $A$. electrum and three further extant species (A. fuscoauratus, A. limifrons and A. aculiventris) as proposed by Lazell (1965) was not inferred in any of the most parsimonious trees, a Wilcoxon signed-rank (WSR) test failed to show statistical differences between unconstrained optimal trees and topologically constrained parsimonious trees (Castañeda et al., 2014). Therefore, no evidence suggests that this fossil species has the closest similarity to Anolis limifrons, therefore $A$. electrum may be of no help in tracing anole evolution. As a result, Nicholson et al. (2012) failed to speculate on the time of origin and differentiation of anoles.

In addition, three further Mexican amber specimens have been mentioned (in private collections) containing Neogene lizard inclusions (Castañeda et al., 2014), two of which were attributed to the same new Anolis species described by Martínez-Grimaldo et al. (2013), while no detailed descriptions were given for these.

\section{Dominican specimens}

Inclusions in Dominican amber are the best preserved of all known fossil amber inclusions (Grimaldi \& Engel, 2005). The report of the first nearly complete vertebrate fossil in amber (NMBA Entomology P 52, SVL $\approx 26.5 \mathrm{~mm}$ ) was described by Rieppel (1980b) and named $A$. dominicanus. The characteristics of scansorial toe pads on the ventral surface of the endmost part of the toes clearly indicate that the specimen, which was found in the La Toca amber mine in the Cordillera Septentrional region of the Dominican Republic, should be classified as Anolis (Rieppel, 1980b). It can be attributed to the Alpha Anolis group due to the lack of transverse processes on the caudal vertebrae. Anolis on The Caribbean islands (including The Bahamas, The Great Antilles and The Lesser Antilles) are divided into six ecomorphs (or ecomorphological types) based on body length, limb length, subdigital lamellae, tail length, body colour and habitat (Williams, 1972, 1983). The NMBA specimen accords with Williams' definition of the "green anole species group" of Hispaniola (Williams, 1972), therefore it should be assigned to the crown ecomorph.

It was widely believed that Anolis appeared on the Caribbean islands (i.e., the West Indies) later than the Early Miocene flooding events. But there had been no record of pre-Pleistocene Anolis by then. The finding of $A$. dominicanus suggests that Anolis appeared there as early as the Miocene (Rieppel, 1980a), much earlier than the estimated time of subsequent evolution and spread of the Alpha Anolis type on the Greater Antilles.

The second record of Dominican amber lizard 
(AMNH DP-SH-1) was described by De Queiroz et al. (1998) of the American Museum of Natural History, the skeleton and general morphology of which was similar to that of $A$. dominicanus. This has several morphological features not seen in the A. dominicanus holotype (NMBA Entomology $\mathrm{P}$ 52). Accordingly, there is no evidence to suggest that these two specimens are synonymous. As the specimen had squamation features and a snoutvent length of $\sim 29 \mathrm{~mm}$, it was inferred to be a hatchling thereby compared with 66 juvenile specimens belonging to five extant Anolis species from Hispaniola (De Queiroz et al, 1998). In the end, given their postcranial characteristics and scale patterns both AMNH DP-SH-1 and $A$. dominicanus were assigned to the $A$. chlorocyanus species group, and the $\mathrm{T}$ clade (Savage \& Guyer, 1989), though AMNH DP-SH1 had not been named yet. Morphological analysis suggests that the AMNH DP-SH-1 specimen should be assigned to the tree-trunk ecomorph (De Queiroz et al., 1998).

The third amber inclusion anole (SMU 74976) from the Dominican Republic was described by Polcyn et al. (2002). Only a relatively complete skull, the first six cervical vertebrae, part of the soft tissue and a few scales were preserved. Based on HRXCT data and the reconstructed digital image, the specimen shows a missing splenial bone in the lower jaw, indicating that AMNH DPSH-1 can be definitely attributed to the T clade. Considering Poe's summary of the characteristics of the dwarf twig Anolis on Hispaniola island (Poe, 1998), this specimen was certainly not a twig Anolis, but one similar to AMNH DP-SH-1, possibly a tree-trunk ecomorph. Even though the first two specimens discussed above were classified as $\mathrm{T}$ clade anoles, the lack of splenial bone in these can be confirmed, further evidencing their attribution. Therefore, the AMNH DP-SH-1 finding clearly confirms the existence of T-clade anoles in the Miocene (Polcyn et al., 2002).

Thirty-five further specimens of Dominican amber lizards were described with detailed morphological analyses of 17 new specimens, as well as three previously described specimens by Sherratt et al. (2015). A Discriminant Function Analysis (DFA) was conducted on based on specimen size and the number of lamellae, resulting in 14 specimens $($ DFA $>0.9)$ divided 46 into four ecomorphs. Nine were classified as the trunk-crown ecomorph, two the trunk-ground ecomorph, two the trunk ecomorph, with the last one being the twig ecomorph. According to a Bayesian phylogenetic analysis and parsimony method, the above 14 specimens were all attributed to the crown Anolis. However, 6 specimens remained temporarily unclassified. Therefore, it can be inferred that there are at least four different Anolis species in Dominican amber. In addition, Dominican lizard inclusions show the same ecomorphological structure as modern anoles living on the island of Hispaniola (Sherratt et al., 2015), although the crown-giant and grassbush ecomorphs are absent from these specimens as they may have been unlikely to get caught by the resin due to their behavior. On the whole, fossil data and phylogenetic analysis results revealed that the ecomorphological radiation began very early, namely that the ecomorphological structure of Anolis in Hispaniola could have formed as early as the Miocene and stay the same. The ancient community structure may have persisted to the structure present in the anole groups of Hispaniola today, partly reflecting the stability of ecological communities on a macroevolutionary timescale (Losos et al., 1998; Mahler et al., 2013; Williams, 1983).

Two specimens (ZFMK 66238, SVL = $32.1 \mathrm{~mm}$; SMNS Do-3584-M, SVL = $16.5 \mathrm{~mm}$ ) were described by Böhme (1984) from the La Toca mine and named S. dommelis. Sphaerodactylus had once been identified as member of Iguanidae and classified an anoline lizard due to its resemblance of anoles in its morphology (considering limb proportions and skull shape). However, its attribution was controversial due to the asymmetry of its ungual sheath, typical of the family Gekkonidae (Böhme, 1984; Gamble et al., 2011; Kluge, 1995). A digital x-ray analysis on the holotype (ZFMK 66238) and paratype (SMNS Do-3584-M) of Sphaerodactylus dommelis was later conducted by Daza et al. (2012), obtaining new osteological characteristics and further anatomical information. Two important new features were shown in the x-ray images: (1) The tail of the holotype is disconnected from the sixth caudal vertebra, hence it can be inferred that the tail had regenerated, a phenomenon commonly occurring 
in Sphaerodactylus and other geckos; (2) There is only one egg in the abdomen of the holotype, corresponding to the fact that Sphaerodactylus lizards develop single-egg clutches. The gestation state and the terminal fusion of the epiphyses in the individual indicate that the holotype was an adult (Maisano, 2000, 2002). The results of morphological analysis pointed out that nine recognition features of Sphaerodactylus dommelis was consistent with those of gekkotans and with seven of Sphaerodactylus, so it could be clearly attributed to Sphaerodactylus; it would also be helpful to calibrate when they existed within the time tree of geckos (Daza \& Bauer, 2012; Daza et al., 2012).

A new finding of a Dominican amber gecko (AMNH collection, $\mathrm{SVL} \approx 14 \mathrm{~mm}$ ) was described by Kluge (1995). The specimen is small, has a short snout, small and slightly overlapping dorsal scales, and shows slight ossification. Based on the obvious asymmetry of the ungual sheath, it was attributed to Sphaerodactylus. By comparing it with $S$. dommelis, Kluge concluded they were different species, but he did not name the specimen.

A new species named $S$. ciguapa (holotype: MCZ $\mathrm{R}-186380, \mathrm{SVL} \approx 33 \mathrm{~mm}$ ) was described by Daza \& Bauer et al. (2012) from the La Toca mine of the Dominican Republic. The specimen is highly ossified with the skeleton being nearly complete, part of the integument remaining, and the typical scale pattern of Sphaerodactylus shown on the left manus. Since the time of formation of Dominican amber $(\sim 20-15 \mathrm{Ma})$ is close to that of the Mona Passage or the separation of Hispaniola and Puerto Rico ( 16-11 Ma) (MacPhee et al., 2003), ten extant species from Puerto Rico, 35 modern species from Hispaniola and fossils found previously were compared with the new species (Daza \& Bauer, 2012). The results show that the SVL of R-186380 is similar to that of 17 species in Hispaniola, four species in Puerto Rico and the fossil species $S$. dommelis, while other features such as the smaller dorsal scales and keeled scales are different from those of other species. Compared with $S$. dommelis, the new specimen has a shorter neck and smaller, more granular, slightly imbricate to unkeeled dorsal scales (Daza 6 Bauer, 2012; Daza et al., 2014). According to topological analysis $S$. ciguapa has 258 features in total, some of which typical of Sphaerodactylus.
Its phenotype is similar to $S$. difficilis, but the relationship between species is still unknown, therefore it is not possible to do a tentative reconstruction of the Miocene Sphaerodactylus fauna.

Recently, Barthel et al. (2020) experimented on the isolated left forelimb of a new Dominican specimen (SMNS DHQ-4924-H), which was assigned to Anolis sp., and verified that the preservation of vertebrates in amber was strongly effected by chemical exchange with the resin environment in an open system. However, there is no description of morphology and anatomy of the specimen.

\section{Other lizard inclusions}

Undoubtedly, a number of amber lizards not yet mentioned here are found in private collections. For instance, Grimaldi (1996) referred to a private collection with Sphaerodactylus specimens in his work, but there is only one figure given without further elaboration. Additionally, there are about six other specimens of Sphaerodactylus all of which in private collections, with the exact origin of the amber unknown. Grimaldi et al. (2000) described a specimen belonging to an Italian collector, Dott. Ettore Morone. This is wellpreserved with an integument, and the tail being regenerated. It was also attributed to the Sphaerodactylus genus (Grimaldi et al., 2000), but the rest of the information is quite unclear.

Furthermore, there is a number of inclusions of lizard skin that are too poorly preserved to be distinguished (Perrichot \& Néraudeau, 2005).

\section{Conclusions}

We summarized all of the published lizard inclusion material around the world herein. It is remarkable that of 83 such specimens, 22 are kept in public institutions, whereas 61 are in private collections accounting for $73.5 \%$. Nine new species were described from amber inclusions, with eight holotypes kept in public institutions and one in a private collection, the latter accounting for 11 percent. Of all published specimens in public institutions, those where the majority of the whole body (including the head) 
is complete (missing part of leg or the end of tail) account for $18.2 \%$, those with the head present make up $50 \%$, and those with identifiable scales amount to $91 \%$.

The use of private collections for future research should be minimized. Even though a high number of images produced by three-dimensional scanning and models of 3D printing are stored in public institutions, the inability of viewing original specimens remains a serious problem for visiting scholars.

Based on the main morphological characteristics, phylogenetic status and importance of specimens discussed above, we came to the following conclusions:

(1) Lizard inclusions in amber generally involve small-sized individuals, which may be due to their average mass ratio and behavior (Arnold et al., 2002).

(2) During the Cretaceous period, the typical external characteristics of early members of autarchoglossans developed, while the typical toe proportions of climbing geckos also formed. Fossil evidence shows that the Cretaceous lizard fauna in Myanmar consists of at least five groups including the stem Squamata, the stem Gekkota, the crown Agaminae, the crown Lacertoidea and the stem Anguimorpha. This fauna was diverse already as early as the midCretaceous.

(3) Paleogene lizard inclusions in amber are dominated by the crown Lacertoidea (Succinilacerta spp.) and the Gekkonidae (Yantarogekko balticus). Due to the generally poor preservation of specimens, further phylogenetic analysis cannot be conducted. Thereby, the level of research on these is still rudimentary.

(4) Neogene lizard inclusions in amber are the most abundant of all, are more closely related to modern lizards, and are represented by two extant genera: Sphaerodactylus (Gekkonidae) and Anolis (Iguanidae). Three Miocene specimens of Sphaerodactylus represent the earliest records of the genus. A complex ecomorphological structure of Anolis spp. found in Dominican amber indicates that the community structure can be stable on a macroscopic time scale.

Generally, amber inclusions can provide details that traditional fossils cannot, and the study of inclusions in amber is a great compliment to research on traditional fossils. Studies of lizard inclusions in amber covering the past half century partly fill the gap in the knowledge of evolutionary history of several lizard clades, and were essential to understand the evolution of ecological community structure and adaptive radiation (such as Anolis), the origin and evolution of geckos' adhesion mechanism, as well as the diversity of the pre-Quaternary lizard fauna. However, many unstudied collections remain. The publication of more lizard inclusion studies in the future would be helpful to further refine the systematic classification of lizards and improve the understanding of the evolutionary history of certain taxa.

\section{Acknowledgements}

This research was funded by the National Natural Science Foundation of China (No. 41790455, 41772008).

\section{References}

Arnold, E. N. (1973). Relationships of the Palaeartic lizards assigned to the genera Lacerta, Algyroides and Psammodromus (Reptilia: Lacertidae). Bulletin of the Natural History Museum Zoology, 25(8), 291-366.

Arnold, E. N. (1998). Structural niche, limb morphology and locomotion in lacertid lizards (Squamata, Lacertidae), a preliminary study. Bulletin of the Natural History Museum Zoology, 64, 63-89.

Arnold, E. N., Azar, D., Ineich, I., \& Nel, A. (2002). The oldest reptile in amber: a 120million-year-old lizard from Lebanon. Journal of Zoology, 258(1), 7-10.

Arnold, E. N., \& Poinar, G. (2008). A 100million-year-old gecko with sophisticated adhesive toe pads, preserved in amber from Myanmar. Zootaxa, 1847, 62-68. http://dx.doi.org/10.11646/zootaxa.1847.1.5 Autumn, K., \& Peattie, A. M. (2002). 
Mechanisms of adhesion in geckos. Integrative and Comparative Biology, 42(6), 1081-1090.

https://doi.org/10.1093/icb/42.6.1081

Böhme, W. (1984). Erstfund eines fossilien Kugelfingergeckos (Sauria: Gekkonidae: Sphaerodactylinae) aus Dominikanischem Bernstein (Oligozän von Hispaniola, Antillen). Salamandra, 20, 212-220.

Böhme, W., \& Weitschat, W. (1998). Redescription of the Eocene lacertid lizard Nucras succinea Boulenger, 1917 from Baltic amber and its allocation to Succinilacerta n. gen. Mitteilungen. Geologische-Paläontologische Insitut Universität Hamburg, 81, 203-222.

Böhme, W., \& Weitschat, W. (2002). New finds of lizards in Baltic Amber (Reptilia: Squamata: Sauria: Lacertidae). Faunistische Abhandlungen Staatliches Museum für Tierkunde Dresden, 23(6), 117-130.

Barthel, H. J., Fougerouse, D., Geisler, T., \& Rust, J. (2020). Fluoridation of a lizard bone embedded in Dominican amber suggests open-system behavior. PloS One, 15(2), e0228843.

Bauer, A. M. (2019). Gecko adhesion in space and time: A phylogenetic perspective on the scansorial success story. Integrative and comparative biology, 59(1), 117-130. https://doi.org/10.1093/icb/icz020

Bauer, A. M., Böhme, W., \& Weitschat, W. (2005). An Early Eocene gecko from Baltic amber and its implications for the evolution of gecko adhesion. Journal of Zoology, 265(4), 327-332.

https://doi.org/10.1017/S095283690400625 $\underline{9}$

Bolet, A., \& Evans, S. E. (2010). A new lizard from the Early Cretaceous of Catalonia (Spain), and the Mesozoic lizards of the Iberian Peninsula. Cretaceous Research, 31(4), 447-457. https://doi.org/10.1016/j.cretres.2010.06.00 2

Borsuk-Bialynicka, M., Lubka, M., \& Bohme, W. (1999). A lizard from Baltic amber [Eocene] and the ancestry of the crown group lacertids. Acta Palaeontologica Polonica, 44(4), 349382.

Boulenger, G. A. (1917). A revision of the lizards of the genus Nucras. Annals of the South
African Museum, 13(10), 196-216.

Boulenger, G. A. (1920). Monograph of the Lacertidae (vol. 1). London: Trustees of the British Museum (Natural History).

Castañeda, M. D. R., Sherratt, E., \& Losos, J. (2014). The Mexican amber anole, Anolis electrum, within a phylogenetic context: implications for the origins of Caribbean anoles. Zoological Journal of the Linnean Society, 172(1), 133-144. https://doi.org/10.1111/zoj.12159

Conrad, J. L., \& Norell, M. A. (2007). A complete Late Cretaceous iguanian (Squamata, Reptilia) from the Gobi and identification of a new iguanian clade. American Museum Novitates, 2007(3584), 1-47. https://doi.org/10.1206/00030082(2007)3584[1:ACLCIS]2.0.CO;2

Conrad, J. L. (2008). Phylogeny and systematics of Squamata (Reptilia) based on morphology. Bulletin of the American Museum of Natural History, 2008(310), 1-182. https://doi.org/10.1206/310.1

Daza, J. D., \& Bauer, A. M. (2012). A new amberembedded sphaerodactyl gecko from Hispaniola, with comments on morphological synapomorphies of the Sphaerodactylidae. Breviora, 529(1), 1-28. https://doi.org/10.3099/529.1

Daza, J. D., Bauer, A. M., \& Snively, E. D. (2014). On the fossil record of the Gekkota. The Anatomical Record, 297(3), 433-462. https://doi.org/10.1002/ar.22856

Daza, J. D., Bauer, A. M., Stanley, E. L., Bolet, A., Dickson, B., \& Losos, J. B. (2018). An enigmatic miniaturized and attenuate whole lizard from the Mid-Cretaceous amber of Myanmar. Breviora, 563(1), 1-18. https://doi.org/10.3099/MCZ49.1

Daza, J. D., Bauer, A. M., Wagner, P., \& Böhme, W. (2013). A reconsideration of $\mathrm{S}$. phaerodactylus dommeli B öhme, 1984 (Squamata: Gekkota: S. phaerodactylidae), a $\mathrm{M}$ iocene lizard in amber. Journal of Zoological Systematics and Evolutionary Research, 51(1), 55-63. https://doi.org/10.1111/jzs.12001

Daza, J. D., Stanley, E. L., Wagner, P., Bauer, A. M., \& Grimaldi, D. A. (2016). MidCretaceous amber fossils illuminate the past diversity of tropical lizards. Science Advances, 2(3), e1501080. 
https://doi.org/10.1126/sciadv.1501080

De Queiroz, K., Chu, L. R., \& Losos, J. B. (1998). A second Anolis lizard in Dominican Amber and the systematics and ecological morphology of Dominican Amber Anoles. American Museum Novitates, (3249), 1-24.

Dejax, J., Masure, E., \& Azar, D. (1996). Analyse palynologique d'un échantillon de sédiment du Crétacé inférieur du Liban. Strata, 1(8), 66-67.

Dejax, J., Masure, E., \& Azar, D. (1997). Analyse palynologique de deux échantillons de sédiment du Crétacé inférieur du Liban. XVème Symposium de l'Association des Palynologues de Langue Française. Lyon 13 Septembre 1997, pp. 20-21.

Estes, R., De Queiroz, K., \& Gauthier, J. (1988). Phylogenetic relationships within Squamata. Phylogenetic relationships of the lizard familie (Eds: R Estes, \& G Pregill). Stanford: Stanford University Press, 119-281.

Etheridge, R. (1959). The relationships of the anoles (Reptilia: Sauria: Iguanidae): an interpretation based on skeletal morphology (Unpublished doctoral dissertation). University of Michigan, Ann Arbor, Michigan, U.S.A.

Etheridge, R. (1965). The abdominal skeleton of lizards in the family Iguanidae. Herpetologica, 21(3), 161-168.

Fontanarrosa, G., Daza, J. D., \& Abdala, V. (2018). Cretaceous fossil gecko hand reveals a strikingly modern scansorial morphology: qualitative and biometric analysis of an amber-preserved lizard hand. Cretaceous Research, 84, 120-133. https://doi.org/10.1016/j.cretres.2017.11.00 $\underline{3}$

Gamble, T., Bauer, A. M., Greenbaum, E., \& Jackman, T. R. (2008). Evidence for Gondwanan vicariance in an ancient clade of gecko lizards. Journal of Biogeography, $35(1)$, 88-104. https://doi.org/10.1111/j.13652699.2007.01770.x

Gamble, T., Daza, J. D., Colli, G. R., Vitt, L. J., \& Bauer, A. M. (2011). A new genus of miniaturized and pug-nosed gecko from South America (Sphaerodactylidae: Gekkota). Zoological Journal of the Linnean Society, 163(4), 1244-1266. https://doi.org/10.1111/j.1096- $\underline{3642.2011 .00741 . \mathrm{x}}$

Gao, K., \& Norell, M. A. (2000). Taxonomic composition and systematics of Late Cretaceous lizard assemblages from Ukhaa Tolgod and adjacent localities, Mongolian Gobi Desert. Bulletin of the American Museum of Natural History, 2000(249), 1$118 . \quad$ https://doi.org/10.1206/00030090(2000)249\%3C0001:TCASOL\%3E2.0 . $\mathrm{CO} ; 2$

Grimaldi, D., \& Engel, M. S. (2005). Evolution of the Insects. Cambridge University Press, New York.

Grimaldi, D., Nguyen, T., \& Ketcham, R. (2000). Ultra-high-resolution X-ray computed tomography (UHR CT) and the study of fossils in amber. In: D. Grimaldi (Ed), Studies of Fossils in Amber, with Particular Reference to the Cretaceous of New Jersey. Leiden, The Netherlands: Backhuys Publishers.

Grimaldi, D. A. (1995). The Age of Dominican Amber. American Chemical Society, Washington, pp. 203-217.

Grimaldi, D. A. (1996). Amber: Window to the Past. New York: Harry N. Abrams.

Grimaldi, D. A., Bonwich, E., Delannoy, M., \& Doberstein, S. (1994). Electron microscopic studies of mummified tissues in amber fossils. American Museum Novitates, 3097, $1-31$.

Hutchinson, M. N., Skinner, A., \& Lee, M. S. (2012). Tikiguania and the antiquity of squamate reptiles (lizards and snakes). Biology Letters, 8(4), 665-669. https://doi.org/10.1098/rsbl.2011.1216

Itturralde-Vinent, M. A., \& Macphee, R. D. E. (1996). Age and paleogeographical origin of Dominican Amber. Science, 273, 1850-1852. https://doi.org/10.1126/science.273.5283.18 $\underline{50}$

Katinas, V. (1983). Baltijos Gintaras. Vilnius: Mokslas.

Keyser, D., \& Weitschat, W. (2005). First record of ostracods (Crustacea) in Baltic amber. Hydrobiologia, $\quad 538(1-3), \quad$ 107-114. https://doi.org/10.1007/s10750-004-5941-5

Klebs, R. (1889). Ueber die Fauna des Bernsteins. Versammlung Deutscher Naturforscher und Ärzte in Heidelberg, 62, 268-271.

Klebs, R. (1910). Über Bernsteineinschlüsse im allgemeinen und die Coleopteren meiner 
Bernsteinsammlung. Schriften der Physikalisch-Ökonomischen Gesellschaft zu Königsberg, 51, 217-242.

Kluge, A. G. (1995). Cladistic relationships of sphaerodactyl lizards. American Museum Novitates, 3139, 1-23.

Kosmowska-Ceranowicz, B., Kulicka, R., \& Gierlowska, G. (1997a). A lizard found in Baltic amber. Gdansk Museum of the Earth, Scientific Conferences. Abstracts, 9, 23-24.

Kosmowska-Ceranowicz, B., Kulicka, R., Gierlowska, G. (1997b). Nowe znalezisko jaszczurki w bursztynie baltyckim. Przeglad Geologiczny, 45(10), 1028-1030.

Krumbiegel, G. (1998). Eidechsenfund im Baltischen Bernstein. Fossilien, 2, 231-235.

Langenheim, J. H. (1966). Botanical source of amber from Chiapas. Ciencia, 24, 201-211.

Lazell, Jr. J. D. (1965). An Anolis (Sauria, Iguanidae) in amber. Journal of Paleontology, 379-382.

Losos, J. B., Jackman, T. R., Larson, A, De Queiroz, K., \& Rodríguez-Schettino, L. (1998). Contingency and determinism in replicated adaptive radiations of island lizards. Science, 279(5359), 2115-2118.

MacPhee, R. D., Iturralde-Vinent, M. A., \& Gaffney, E. S. (2003). Domo de Zaza, an Early Miocene Vertebrate Locality in SouthCentral Cuba, with Notes on the Tectonic Evolution of Puerto Rico and the Mona Passage1. American Museum Novitates, 2003(3394), $1-42$. https://doi.org/10.1206/00030082(2003)394\%3C0001:DDZAEM\%3E2. $0 . \mathrm{CO} ; 2$

Mahler, D. L., Ingram, T., Revell, L. J., \& Losos, J. B. (2013). Exceptional convergence on the macroevolutionary landscape in island lizard radiations. Science, 341(6143), 292-295. https://doi.org/10.1126/science.1232392

Maisano, J. A. (2000). Postnatal skeletal development in squamates: Its relationship to life history and potential phylogenetic informativeness (Doctoral thesis, Yale University, U.S.A). Retrieved from https://www.elibrary.ru/item.asp?id=5294 $\underline{834}$

Maisano, J. A. (2002). Terminal fusions of skeletal elements as indicators of maturity in squamates. Journal of Vertebrate Paleontology, 22, 268-275.
Manthey, U., \& Schuster, N. (1996). Agamid lizards. Neptune City, New Jersey: TFH Publications.

Martínez-Grimaldo, R. E., Riquelme, F., Martínez-Méndez, N., Luna, B., Zúniga, L., Alvarado-Ortega, J., Loso, J. B., \& Castañeda, M. D. R. (2013). Anole lizards (Squamata: Dactyloidae) from the Miocene Chiapas amber, with comments on broader aspects of anoles evolution. Paper presented at the VIII Congreso Latinoamericano de Paleontología \& XIII Congreso Mexicano de Paleontología. Sociedad Mexicana de Paleontología, Guanajuato, México, pp. 63.

Martínez-Delclòs, X., Briggs, D. E., \& Peñalver, E. (2004). Taphonomy of insects in carbonates and amber. Palaeogeography, Palaeoclimatology, Palaeoecology, 203(12), 19-64. https://doi.org/10.1016/S00310182(03)00643-6

Matsumoto, R., \& Evans, S. E. (2018). The first record of albanerpetontid amphibians (Amphibia: Albanerpetontidae) from East Asia. PloS One, 13(1). https://dx.doi.org/10.1371\%2Fjournal.pone. 0189767

Morayma Solórzano Kraemer, M. (2007). Systematic, palaeoecology, and palaeobiogeography of the insect fauna from Mexican amber. Palaeontographica Abteilung A, 1-133. https://dx.doi.org/10.1127/pala/282/2007/1

Nicholson, K. E., Crother, B. I., Guyer, C., \& Savage, J. M. (2012). It is time for a new classification of anoles (Squamata: Dactyloidae). Zootaxa, 3477(1), 1-108. http://dx.doi.org/10.11646/zootaxa.3477.1.1

Oliver, P. M., \& Sanders, K. L. (2009). Molecular evidence for Gondwanan origins of multiple lineages within a diverse Australasian gecko radiation. Journal of Biogeography, 36(11), 2044-2055. https://doi.org/10.1111/j.13652699.2009.02149.x

Penney, D. (2010). Biodiversity of fossils in amber from the major world deposits. The United Kingdom: Siri Scientific Press, Manchester.

Perrichot, V., \& Néraudeau, D. (2005). Reptile skin remains in the Cretaceous amber of France. Comptes Rendus Palevol, 4(1-2), 47-51.

https://doi.org/10.1016/j.crpv.2004.11.009 
Pianka, E. R., \& Vitt, L. J. (2003). Lizards: windows to the evolution of diversity (vol. 5). Berkeley: University of California Press.

Poe, S. (1998). Skull characters and the cladistic relationships of the Hispaniolan dwarf twig Anolis. Herpetological Monographs, 122, 192-236.

Poe, S. (2004). Phylogeny of anoles. Herpetological Monographs, 18(1), 37-89.

Poinar, J. G., Philbrick, K. A., Cohn, M. J., Turner, R. T., Iwaniec, U. T., \& Wunderlich, J. (2017). X-ray microcomputed tomography reveals putative trematode metacercaria in a 100-million-year-old lizard (Squamata: Agamidae). Cretaceous Research, 80, 27-30. https://doi.org/10.1016/j.cretres.2017.07.01 $\underline{7}$

Poinar, J. G. (1992). Life in amber. Standford, California: Standford University Press.

Poinar, J. G., \& Brown, A. E. (2002). Hymenaea mexicana sp. nov. (Leguminosae: Caesalpinioideae) from Mexican amber indicates Old World connections. Botanical Journal of the Linnean Society, 139, 125132. $\quad$ https://doi.org/10.1046/j.10958339.2002.00053.x

Polcyn, M. J., Rogers, J. V., Kobayashi, Y., \& Jacobs, L. L. (2002). Computed tomography of an Anolis lizard in Dominican amber: systematic, taphonomic, biogeographic, and evolutionary implications. Palaeontologia Electronica, 5(1), 1-13.

Reilly, S. M., McBrayer, L. B., \& Miles, D. B. (2007). Lizard ecology, the evolutionary consequences of foraging mode. Cambridge, UK: Cambridge University Press.

Rieppel, O. (1980a). The phylogeny of anguinomorph lizards. Denkschriften der Schweizerischen Naturforschenden Gesellshaft, 94, 1-86.

Rieppel, O. (1980b). Green anole in Dominican amber. Nature, 286(5772), 486-487.

Rieppel, O. (1994). The Lepidosauromorpha: an overview with special emphasis on the Squamata. In N. C. Fraser \& H-D. Sues (Eds), In the Shadow of the Dinosaurs. NewYork: Cambridge University Press.

Ritzkowski, S. (1997). K-Ar-Altersbestimmung der Bernsteinfuhrenden Sedimente des Samlandes (Palaogen, Bezirk Kaliningrad). Metalla (Sonderheft), 66, 19-23.

Russell, A. P., \& Bauer, A. M. (1989). Ungual asymmetry in the context of pedal symmetry in Ailuronyx (Reptilia Gekkonidae): Modification for an opposable grip. Journal of Zoology, 218(1), 1-9.

Russell, A. P., \& Bauer A. M. (1990). Digit I in pad-bearing gekkonine geckos: alternate designs and the potential constraints of phalangeal number. Memoirs of the Queensland Museum, 29, 453-472.

Savage, J. M., \& Guyer, C. (1989). Infrageneric classification and species composition of the anole genera, Anolis, Ctenonotus, Dactyloa, Norops, and Semiurus (Sauria: Iguanidae). Amphibia-Reptilia, 10, 105-116. https://doi.org/10.1163/156853889X00142

Sherratt, E., del Rosario Castañeda, M., Garwood, R. J., Mahler, D. L., Sanger, T. J., Herrel, A., \& Losos, J. B. (2015). Amber fossils demonstrate deep-time stability of Caribbean lizard communities. Proceedings of the National Academy of Sciences, 112(32), 9961-9966. https://doi.org/10.1073/pnas.1506516112

Shi, G., Grimaldi, D. A., Harlow, G. E., Wang, J., Wang, J., Yang, M., \& Li, X. (2012). Age constraint on Burmese amber based on $\mathrm{U}-\mathrm{Pb}$ dating of zircons. Cretaceous research, 37, 155-163. https://doi.org/10.1016/j.cretres.2012.03.01 $\underline{4}$

Simões, T. R., Caldwell, M. W., Nydam, R. L., \& Jiménez-Huidobro, P. (2017). Osteology, phylogeny, and functional morphology of two Jurassic lizard species and the early evolution of scansoriality in geckoes. Zoological Journal of the Linnean Society, 180(1), 216-241. https://doi.org/10.1111/zoj.12487

Wichard, W., \& Weitschat, W. (2002). Atlas of plants and animals in Baltic amber. München: Verlag Dr. Friedrich Pfeil.

Williams, E. E. (1972). The Origin of Faunas. Evolution of Lizard Congeners in a Complex Island Fauna: A Trial Analysis. New York: Springer.

Williams, E. E. (1976). West Indian anoles: A taxonomic and evolutionary summary 1 . Introduction and a species list. Breviora, 440, 1-21.

Williams, E. E. (1983). Ecomorphs, faunas, island size, and diverse end points in island radiation of Anolis. In: L. J. Vitt \& E. R. 
Pianka (Eds.), Lizard ecology: historical and experimental perspectives. Princeton, N.J.: Princeton University Press.

Williams, E. E. (1989). A critique of Guyer and Savage (1986): cladistic relationships among anoles (Sauria: Iguanidae): are the data available to reclassify the anoles? In: C. A. Woods (Ed.), Biogeography of the West Indies: Past, Present, Future. Gainesville, FL: Sandhill Crane Press.

Witten, G. J. (1989). Family Agamidae. In: D. W. Walton, \& B. J. Richardson (Eds.), Fauna of Australia. Canberra: CSIRO Publishing.

Appendix 1. Institutional and other abbreviations.

AMNH: American Museum of Natural History, New York, USA;

AND: The private collection of Scott Anderson, available for study through the American Museum of Natural History, New York, USA.

GAM: Deutsches Bernstein-Museum in Ribnitz-
Damgarten, Germany.

G.G.: The private collection of Mrs. Gabriela Gierlowska, Gdańsk, Poland.

JZC: in James Zigras Collection, available for study through the American Museum of Natural History, New York, USA

MCZ: Museum of Comparative Zoology, Harvard University, Cambridge, USA.

MNHN: Muséum National d'Histoire Naturelle, Paris, France.

MGPU: Museum für Geologie und Paläontologie der Universität in Göttingen, Germany.

NMBA: Naturhistorisches Museum, Basel, Switzerland.

SMNS: Staatliches Museum für Naturkunde Stuttgart, Germany.

SMU: Shuler Museum of Paleontology, Southern Methodist University, Texas, USA.

UCMP: University of California Museum of Paleontology, Berkeley, USA.

ZFMK: Zoologisches Forschungsmuseum Alexander Koenig, Bonn, Germany

Open Access This article is licensed under a Creative Commons Attribution-NoDerivatives 4.0 International (CC BY-ND 4.0) licence, which permits copy and redistribute the material in any medium or format for any purpose, even commercially. The licensor cannot revoke these freedoms as long as you follow the licence terms. Under the following terms you must give appropriate credit, provide a link to the license, and indicate if changes were made. You may do so in any reasonable manner, but not in any way that suggests the licensor endorsed you or your use. If you remix, transform, or build upon the material, you may not distribute the modified material. To view a copy of this license, visit https://creativecommons.org/licenses/by-nd/4.0/. 